\title{
The Effect of Stressor Controllability on Stress-Induced Neuropeptide mRNA Expression within the Paraventricular Nucleus of the Hypothalamus
}

\author{
D. L. Helmreich, L. R. Watkins, ${ }^{*}$ T. Deak, ${ }^{*}$ S. F. Maier, *H. Akil and S. J. Watson \\ University of Michigan, Ann Arbor, MI, USA. *University of Colorado, Boulder, CO, USA.
}

Key words: $\mathrm{CRH}, \mathrm{AVP}$, coping, corticosterone, rat.

\begin{abstract}
Many stressors elicit changes in corticotrophin (CRH), enkephalin (ENK), and neurotensin (NT) mRNA levels within the medial parvocellular region of the paraventricular nucleus of the hypothalamus (mpPVN), and the pattern of changes in mRNA levels appears to depend on the physical characteristics of the stressor. We questioned whether psychologically distinct stressors would cause different patterns of neuropeptide mRNA expression within the PVN. Psychologically distinct stressors were created by employing a paradigm of escapable (controllable) vs non-escapable (yoked) tail shock. An adult male rats could terminate the stress stimulus by performing wheelturning behaviour; his behaviour also terminated the stress for his yoked partner, who had no control over the termination of the shock. Four h post-stress, brains were collected and processed for in-situ hybridization histochemistry. Tail-shock stress stimulated a significant increase in $\mathrm{CRH}$, ENK, and NT mRNA levels within the mpPVN. The number of CRH identified neurones coexpressing AVP mRNA was also significantly elevated in both stress groups. Moreover, the pattern and magnitude of the stress-induced increases in mRNA was similar in both stress groups. Additionally, no stress-induced changes in CRH mRNA levels were observed in the central nucleus of the amygdala. In sum, two psychologically distinct stressors, escapable vs yoked tail shock stress, stimulated similar increases in CRH, NT, ENK, and AVP mRNA levels within the mpPVN. These results suggest that physical attributes of a stress, rather than psychological, may be the more important factors in determining the PVN mRNA response.
\end{abstract}

Activation of the hypothalamic-pituitary-adrenal (HPA) axis can occur by a wide variety of stressful stimuli. Although the final outcome of activation of the axis is similar across stimuli, (i.e. an increase in circulating glucocorticoid concentrations), there is evidence to suggest that the central mechanisms by which stressors activate the HPA axis may differ across stimuli $(1,2)$. Corticosterone secretion from the adrenal gland is stimulated by release of peptides, primarily corticotropin-releasing-hormone $(\mathrm{CRH})$, from the medial parvocellular region of the paraventricular nucleus of the hypothalamus (mpPVN). CRH travels through the portal vasculature to reach the anterior pituitary and stimulates adrenocorticotropin-releasing-hormone (ACTH) secretion, which in turn stimulates corticosterone secretion from the adrenal gland. ACTH secretion is, in part, terminated by negative feedback effects of circulating glucocorticoids. Although $\mathrm{CRH}$ is believed to be the primary ACTH secretagogue (3), there are other peptides, such as vasopressin (AVP), that are colocalized with CRH and can act as ACTH secretagogues (4). Additional peptides, such as enkephalin (ENK) and neurotensin (NT), have also been found within the mpPVN and are colocalized with $\mathrm{CRH}$ (5-7), although their role in the regulation of ACTH secretion is still not well understood.

Acute stressors do alter the regulation of these peptides (CRH, AVP, ENK, and NT), and, interestingly, evidence from many studies suggest that not all stressors affect the regulation of these peptides in the same manner. For example, Plotsky et al. reported that haemorrhage caused an increase in portal blood levels of CRH and AVP (8), while insulin-

Correspondence to: Dana L. Helmreich, Mental Health Research Institute, 205 Zina Pitcher Place, Ann Arbor, MI 48109, USA (dlhelm@umich.edu). 


\section{Stressor controllability and PVN mRNA levels}

induced hypoglycemia caused an increase in portal blood levels of AVP only (9). CRH mRNA has been reported to increase after restraint or hypertonic saline injections but not after ether $(10,11)$ or cold stress $(11,12)$. Conversely, ENK and NT mRNA levels within the PVN have been reported to increase after ether stress (10-12) and restraint stress, but not cold stress (11).

In addition to being categorized by different physical properties, stressors can also be categorized by psychological features, one of which is the degree to which an animal can cope with or control the stressor. For example, animals can cope with stressful events by learning an escape behaviour, such as a bar press or a wheel turn, to terminate the stress stimulus. In certain paradigms aimed at testing the effect of controllability, the coping response of a given animal also terminates the stressor for a yoked partner, who has no control over the stressor. This results in two animals who receive the identical amount, duration, and intensity of the physical stressor, but differ in the psychological aspect of controlling or coping with the stressor. A multitude of previous studies have demonstrated that these two stress conditions have differential effects on a number of parameters altered by stress. For example, stress-induced analgesia (13), prolactin secretion (14), gastric ulcer formation (15), catecholamine system regulation (16), long-term potentiation (17), and learning of new escape responses (18), are differentially impacted by escapable or non-escapable stressors, with the less deleterious effects associated with escapable stress. The deficit in the learning of a new escape response, or learned helplessness, caused by the inescapable stress has been well documented. An animal, previously exposed to inescapable shock, will be unable to learn an appropriate escape response when placed in a new testing environment.

With regard to the regulation of the HPA axis, most data suggest that these two psychologically distinct stress conditions stimulate similar patterns of ACTH and corticosterone secretion $(19,20$; cf 21). However, the ability of the synthetic glucocorticoid dexamethasone to suppress stress-induced corticosterone secretion is dependent on stress controllability, with normal suppression observed in the rats capable of escaping their stress, and incomplete dexamethasone suppression observed in their yoked partners (22; and unpublished data). These results suggest that mechanisms regulating the HPA axis may be different between these two stress conditions.

The impact of psychologically distinct stressors on the regulation of the HPA axis is of particular interest given the interrelationship between stressful life events and clinical depression $(23,24)$, and the dysregulation of the HPA axis that often occurs in clinical depression. Almost all depressed patients have an increased drive to the HPA axis (25), and $\approx 50 \%$ of patients have impaired glucocorticoid negative feedback, as assessed by the dexamethasone suppression test (26). Depressed patients also have an increase in the number of CRH neurones within the PVN (27) and in the number of PVN CRH neurones containing AVP (28). Moreover, it has been proposed that depressed patients may hypersecrete AVP as a result of impaired glucocorticoid feedback (29).

Because some of the same characteristics observed in depressed patients, such as learned helplessness and faulty dexamethasone feedback, can be created in animals using the escapable/yoked stress paradigm, we asked whether we could detect differences in the regulation of the HPA axis, specifically the regulation of PVN neuropeptide mRNAs, between the two psychologically distinct stress conditions. We chose to examine the PVN because it represents the final common path for the flow of information from the central nervous system to the pituitary, and it has been reported that different types of stressors can cause differences in neuropeptide mRNA expression within the mpPVN.

\section{Results}

\section{Plasma corticosterone levels}

Both escapable and yoked tail shock stress stimulated a marked and sustained increase in plasma corticosterone levels (Fig. 1) that did not differ between the two groups. Plasma corticosterone levels in both stress groups remained elevated above the chamber/control group and the home cage group for the duration of the sampling period. There were no significant differences in plasma corticosterone levels between the two control groups. At the time of decapitation, the yoked stress group corticosterone levels were slightly elevated compared to either the chamber/control group or the home cage control group.

\section{PVN mRNA Levels}

CRH mRNA was readily detectable in the control groups, and a stress-induced increase in CRH mRNA was observed in both the escapable and yoked stress groups. The magnitude of the CRH mRNA increase was similar in both the escapable and yoked stress conditions (Figs 2, 3).

In the control animals, ENK mRNA was found within the ventral tail of the parvocellular division of the PVN. After

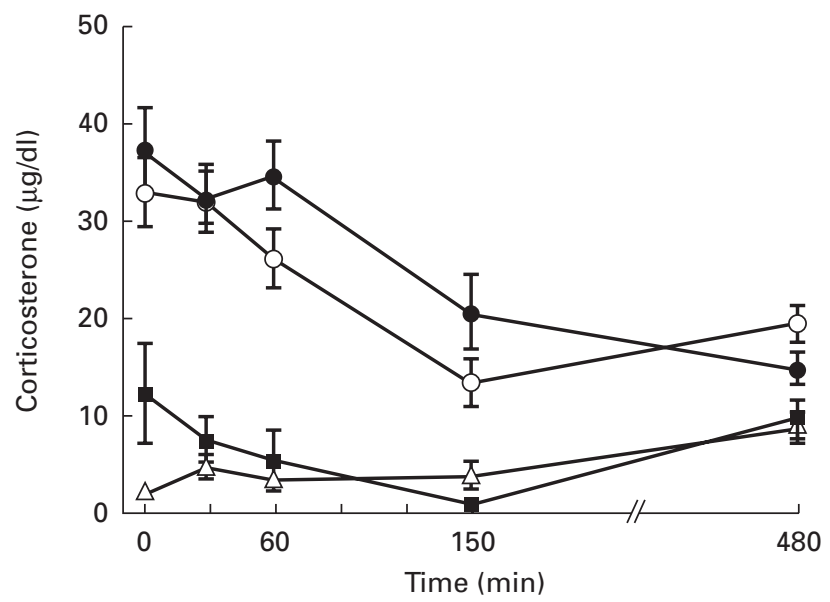

FIG. 1. Mean ( \pm SEM) plasma corticosterone levels measured from 0 to $150 \mathrm{~min}$ after termination of stress. Escapable or yoked stress groups received $1001.0 \mathrm{~mA}$ shocks delivered $30-90 \mathrm{~s}$ apart, with an average intertrial interval of $60 \mathrm{~s}$. Chamber controls were placed in the shock apparatus but did not receive any shock, and home cage controls remained in their cages for the duration of the experiment. Animals were decapitated $480 \mathrm{~min}$ after termination of stress for tissue collection. 

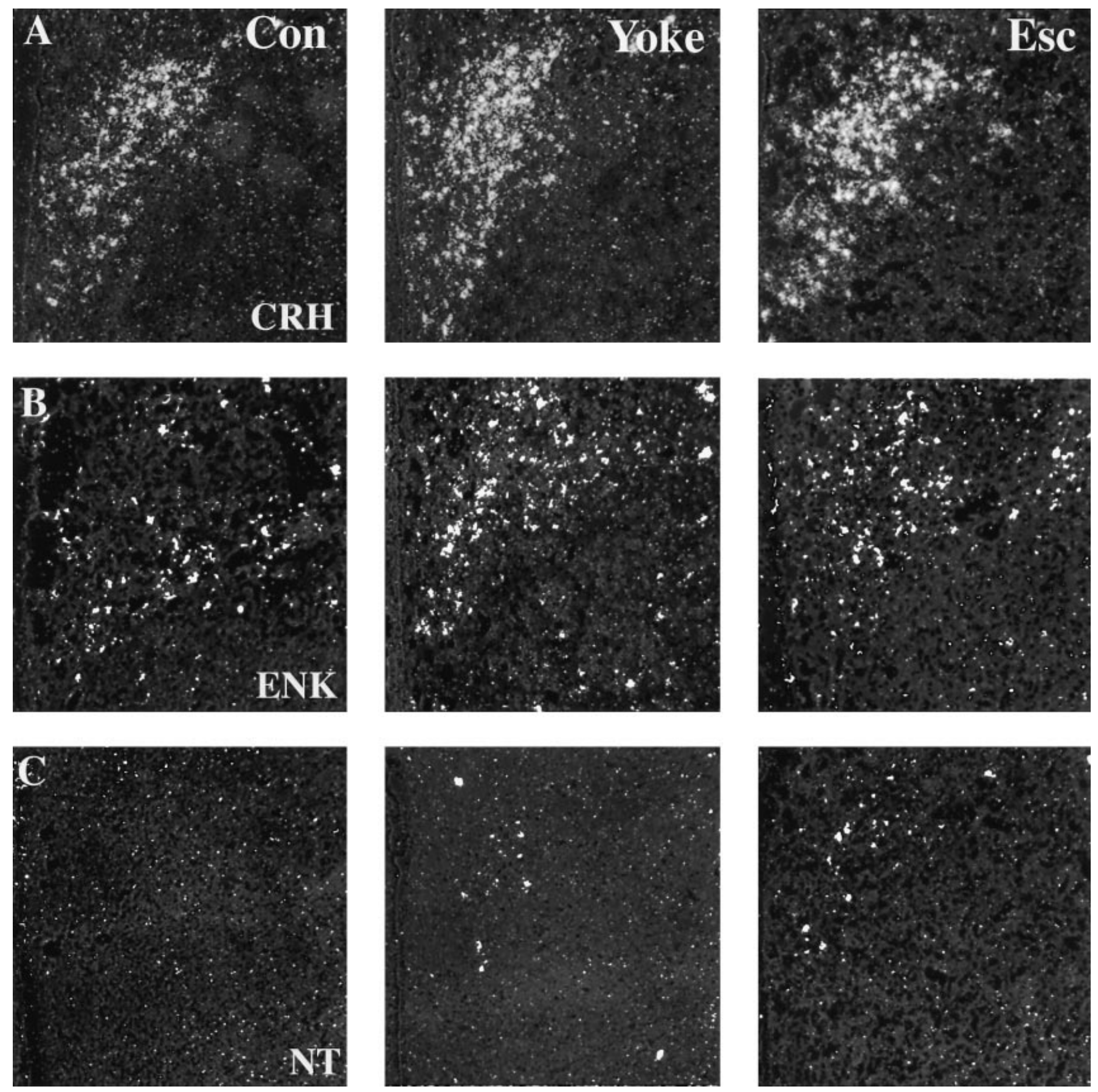

FIG. 2. Photomicrograph illustrating CRH (row A), ENK (row B) or NT (row C) mRNA levels within the PVN of a home cage control animal (left column), an animal exposed to yoked tail shock stress (centre column), and an animal exposed to escapable tail shock stress (right column).

either escapable or yoked tail-shock stress, there was an overall increase in ENK mRNA levels within the PVN, with signal now readily detectable within the medial parvocellular division of the PVN. There was no difference in the pattern or magnitude of this increase in ENK mRNA levels between the escapable or yoked stress conditions (Figs 2, 3).

Within the parvocellular region of the PVN, NT mRNA levels were very low in control animals. Tail-shock stress, either escapable or yoked, stimulated an increase in NT
mRNA levels within the medial parvocellular division of the PVN. Again, the stimulated increase in NT mRNA was similar between both stress conditions (Figs 2, 3).

Double in-situ hybridization techniques were used to determine the number of AVP expressing CRH neurones within the mpPVN. In control conditions, very few neurones were positively identified as containing both $\mathrm{CRH}$ and AVP mRNA. After tail shock stress, there was no change in the number of CRH-dig labelled neurones. However, there was 


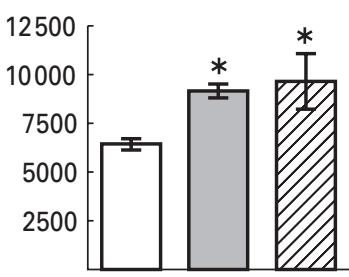

Control Yoke Escape

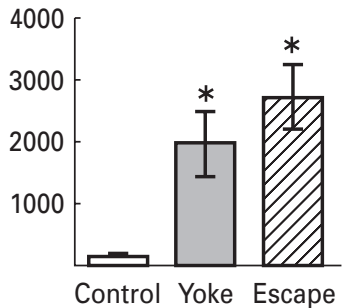

(C)

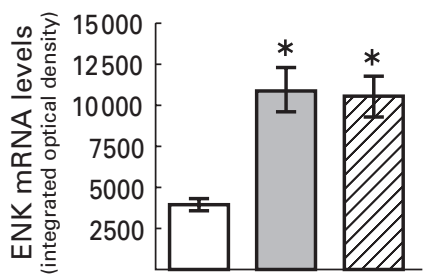

(B)

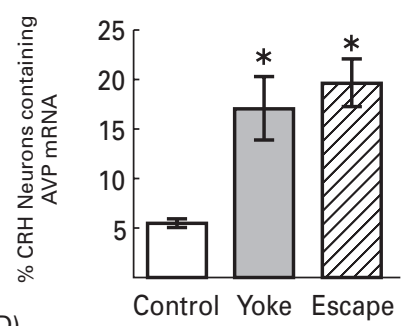

(D)

\section{CeA CRH mRNA}

CRH mRNA was also measured within the central nucleus of the amygdala (CeA). Neither stress condition altered CRH mRNA levels within the CeA. CRH mRNA levels (integrated optical density measurements) were: home cage controls $7460.83 \pm 976.16$; yoked stress group $8954.67 \pm 829.23$; escapable stress group $8272.86 \pm 507.6$.

\section{Discussion}

In the current study, we examined changes in PVN mRNA levels after either escapable or yoked tail shock stress. We found that tail-shock stress, either escapable or yoked, stimulated an increase in the expression of CRH, ENK, and NT mRNA levels within the parvocellular division of the PVN. We were also able to demonstrate that tail-shock stress caused an increase in AVP mRNA levels within CRH neurones. The current stress paradigm induced large changes in neuropeptide gene expression, suggesting a profound impact on HPA axis regulation.

Previous observations that physically distinct stress paradigms led to differences in PVN mRNA expression, median eminence content and secretagogue release (8-12, 30-32) led us to inquire whether psychologically distinct stressors also cause dissimilar patterns of PVN activation. Additionally, the observation that dexamethasone administration is not equally effective in suppressing corticosterone secretion in the escapable $v s$ yoked stress condition (22; unpublished observations) also suggested differences in HPA axis regulation between the two psychologically distinct stress conditions. Given the fact that the suppressing actions of dexamethasone on ACTH and corticosterone secretion have been proposed to initially occur at the anterior pituitary (33), we hypothesized that one way the psychological variable of controllability could be communicated to the anterior pituitary was through differential control of ACTH secretion by the PVN. Although mRNA measurements are an indirect reflection of secretagogue activity, the observed changes in mRNA within the PVN suggest that the two stress conditions had similar effects on the regulation of these peptides, suggesting that the PVN is responding in a similar fashion to both types of stressors. The similar changes in mpPVN mRNA measurements between the two stress conditions also parallel the similar changes in peripheral hormone measurements (i.e. ACTH and corticosterone) caused by the two stress conditions.

In the current study, we found that psychologically distinct stressors do not stimulate different patterns of PVN mRNA expression. It is important to note that the escapable $v s$ yoked tail-shock stress delivered in the manner used in the current study does produce large behavioural and neurochemical differences (34), thus making the failure to detect peptide mRNA differences within the PVN more remarkable. The similarities in stress-induced PVN mRNA changes between the two stress conditions may be because strictly physical, rather than psychological, characteristics of a stressor determine the PVN mRNA response to that particular stimulus. Therefore, because the physical stressor, tail-shock stress, was the same in both stress groups, one might predict that the

FIG. 4. Photomicrograph illustrating a digoxigenin-labelled CRH neurone that coexpresses AVP mRNA (white arrow). A single labelled CRH neurone (black arrow) and an AVP magnocellular neurone (black arrowhead) are also visible. Scale bar $=20 \mu \mathrm{m}$. 
PVN mRNA response would be similar in the two physically similar, but psychologically dissimilar, stress groups. This is not to suggest that psychological factors cannot influence the PVN mRNA response to stress; psychological attributes of physically dissimilar stressors, such as cold $v s$ restraint, may contribute to the reported differences in stress-induced mRNA changes within the PVN.

Alternatively, it may be that dissimilarities in PVN mRNA expression that have been previously reported do not reflect the type of stress, but rather the magnitude of the stressor. For example, when examining the increase in AVP levels within the median eminence after stress, Schmidt et al. (35) reported that the increase in AVP levels was directly correlated with the ACTH response to the stressor, irrespective of the stress stimulus used to activate the HPA axis. Also, we have found that PVN CRH and ENK mRNA levels are significantly correlated with peak ACTH levels, occurring after either ether, restraint, or swim stress (unpublished observations), again suggesting that the magnitude of the stress stimulus (as defined by changes in ACTH secretion) is more closely linked to changes in mRNA levels within the PVN after stress rather than the physical attributes of the stressor. Therefore, because escapable and yoked tail-shock stress stimulate similar levels of HPA axis activation $(19,20)$, current results, unpublished data) we may not have expected to observe differences in pattern and magnitude of mRNA expression within the PVN.

It is also important to remember that this was an acute exposure to the stress condition; it may be that repeated exposure to the stress condition would lead to alterations of the mpPVN response to the stressor. For example, repeated exposure to restraint stress causes a greater AVP mRNA and hnRNA response to acute stress, as compared to the response measured in naive animals (36). Future experiments are needed to determine whether repeated exposure to escapable or yoked stress leads to difference in the magnitude, pattern, or duration of mpPVN neuropeptide mRNA changes.

The function of differential regulation of PVN mRNAs across different stimuli is not clear. These peptides may serve different functions in the regulation of the HPA axis. AVP is known to be an ACTH secretagogue that can potentiate $\mathrm{CRH}$ effects at the level of the anterior pituitary (4). Furthermore, CRH and AVP may alter their own release by acting at the level of the hypothalamus $(37,38)$. NT has a stimulatory effect on ACTH secretion that is dependent on $\mathrm{CRH}$. In contrast to AVP, NT does not have any measurable effect at the level of the pituitary; it may stimulate the HPA axis by acting on receptors located within the hypothalamus (39-41). ENK has been reported to have both stimulatory and inhibitory effects on ACTH and glucocorticoid secretion (42-47). The differential regulation of these peptides by physically dissimilar stressors may reflect different afferent circuits used by stimuli to access the PVN (1). Also, glucocorticoids do not have similar effects on the regulation of mRNAs for these peptides. For example, AVP appears to be exquisitely sensitive to glucocorticoid levels, while mRNA levels for NT and ENK are not altered by elimination of circulating glucocorticoids (48-50). In sum, the differential regulation of peptides within the $\mathrm{PVN}$, both by stressors and glucocorticoids, has been proposed to enable the HPA axis to maintain appropriate responsivity to a broad array of type and duration of stressful stimuli $(51,52)$.

We also examined CRH mRNA levels within the CeA in the current study. Given the observation that the CeA may play a role in behavioural alterations observed after inescapable shock (53-55), and that administration of a $\mathrm{CRH}$ antagonist into the $\mathrm{CeA}$ has been reported to decrease fear associated behaviours, such as freezing $(54,55)$, that occur after inescapable shock, we asked if escapable $v s$ inescapable shock may differentially alter CRH mRNA levels within the CeA. Additionally, CRH mRNA levels in the CeA are positively regulated by glucocorticoids; one might have expected that the increase in corticosterone levels observed after stress would have caused an increase in CRH mRNA levels within the CeA. However, we found absolutely no stress-induced changes in CRH mRNA levels after either escapable or inescapable shock. CRH mRNA levels within the $\mathrm{CeA}$ have been reported to increase if measured immediately after the termination of the stressor $(55,56)$. In the current study, we chose the $4 \mathrm{~h}$ post-stress termination time to kill our animals in order to observe maximal changes in PVN mRNAs (12). This may have prevented us from detecting potentially very transient changes in CRH mRNA levels within the CeA. It is also possible that circulating corticosterone levels were not elevated long enough to cause a change in CRH mRNA levels $(50,57)$. Alternatively, CRH mRNA containing neurones within the CeA may not respond to tail-shock stress. In support of this hypothesis, we have also found that CRH mRNA containing neurones within the $\mathrm{CeA}$ do not respond to interleukin- $1 B$ treatment, as indicated by the lack of colocalization of $c$-fos mRNA within these neurones (58).

The use of controllable $v s$ non-controllable stress paradigms has proven to be a powerful paradigm to begin to understand how stressors alter the regulation of many systems within the body, including the HPA axis, and to begin to explore the powerful impact of psychological variables on the ultimate effect of stressor on an organism. In ongoing studies, we are beginning to use additional tools, such as examining changes in c-fos mRNA, and examining additional circuits, such as the 5-HT system, to learn more about how these psychologically distinct stressors impact the regulation of stress-related systems within the central nervous system.

\section{Materials and methods}

Animals and experimental design

Twenty-eight adult male Sprague Dawley rats, b.w. 350-400 g, were used for these studies. They were housed three to a cage with food and water available ad libitum, and lights in the colony room were on from 07.00 to 19.00 hours. Animals were housed in the colony room for 2 weeks before the experiment. Animals were randomly divided into four experimental groups $(n=7 /$ group $)$; Escapable Stress, Yoked Stress, Apparatus Control and Home Cage Control.

The stress protocol was the same as that used in Grahn et al. (59). Briefly, animals from the escapable stress, yoked stress, and apparatus control groups were placed in $14 \times 11 \times 17 \mathrm{~cm}$ wheel turning boxes. The wheel was two $14-\mathrm{cm}$ disks connected by $9-\mathrm{cm}$ rods. The wheels for the escapable stress groups turned easily, while those in the yoked and apparatus control group did not. Shock was administered to the escapable and yoked stress groups through electrodes fixed to the animals tail; the electrodes were placed $3 \mathrm{~cm}$ apart on the distal part of the animal's tail, augmented with electrode paste and held 


\section{Stressor controllability and PVN mRNA levels}

in place with tape. Shock was generated by a source modelled after a GrasonStadler model 700 shock generator (Quincy, MA, USA).

Each stress session consisted of $1001.0 \mathrm{~mA}$ shocks delivered 30-90 s apart, with an average intertrial interval of $60 \mathrm{~s}$. The duration of the shock for both the escapable and yoked-stressed animal depended on the behaviour of the escapable stress animal. The shock was terminated after $30 \mathrm{~s}$ if the escape subject did not respond. At the beginning of the shock session, a quarter turn of the wheel by the escape stress animal was required to terminate the shock. When three consecutive trials were completed in $<5 \mathrm{~s}$, the response requirement increased by a quarter turn on the next trial. Subsequent trials under $5 \mathrm{~s}$ duration were followed by a $50 \%$ increase in the response requirement until the maximum response requirement of 16 quarter turns was achieved. If the subject failed to respond in $<5 \mathrm{~s}$, following any of these initial trials, the response requirement for the next trial decreased by a quarter turn. Response latencies of $30 \mathrm{~s}$, indicating failure to respond, reset the requirement to the initial quarter turn.

Apparatus control groups were placed in the wheel turning chambers, but they did not receive any tail shock (chamber group). Home cage controls were kept in their home cages and removed only for the tail nick.

A blood sample was collected (via tail nick) immediately after the termination of the stress session $(0 \mathrm{~min})$ and at 30,60 , and $150 \mathrm{~min}$ after the termination of the stress session. Animals were returned to their home cages after the stress session. The stress session was initiated at $08.30 \mathrm{~h}$ and typically lasted $120 \mathrm{~min}$. Animals were killed by decapitation $4 \mathrm{~h}$ post-termination of the stress session. Brains were quickly removed and frozen, and trunk blood was collected for measurement of circulating corticosterone levels.

All procedures were in accordance with NIH guidelines and were approved by the University of Colorado Animal Care and Use Committee.

\section{In-situ hybridization}

Brains were sectioned at $10 \mu \mathrm{m}$ in the coronal plane, and sections were collected onto poly-lysine subbed slides and were stored at $-80^{\circ} \mathrm{C}$ until further processing. In-situ hybridization was conducted using techniques previously described (60). Briefly, sections were removed from the freezer and placed into cold $4 \%$ paraformaldehyde for $60 \mathrm{~min}$. Following washes in $2 \times \mathrm{SSC}$, sections were deproteinated in $0.1 \mu \mathrm{g} / \mathrm{ml}$ proteinase $\mathrm{K}$ at $37^{\circ} \mathrm{C}$ for $10 \mathrm{~min}$, thoroughly rinsed with $2 \times \mathrm{SSC}$, and then were placed in $0.1 \mathrm{M}$ triethanolamine for 15 min to which $0.25 \%$ acetic anhydride had been added. Sections were thoroughly washed with distilled water, and then dehydrated through a series of graded alcohol.

The ${ }^{35}$ S-labelled cRNA probes for $\mathrm{CRH}, \mathrm{ENK}$, and NT mRNA were generated using standard in-vitro transcription methodology. The rat CRH cDNA clone (cDNA courtesy of R. C. Thompson) yielded a $770 \mathrm{nt}$ probe, and the rat ENK cDNA clone yielded a $693 \mathrm{nt}$ probe. NT mRNA levels were detected using a $336 \mathrm{nt}$ probe (cDNA courtesy of P. Dobner) directed against exon 4 of the Neurotensin/Neuromedin gene (61). The probes were labelled in a reaction mixture consisting of $1 \mu \mathrm{g}$ of linearized plasmid, $1 \times$ transcription buffer (Epicentre Technologies, Madison, WI, USA), $125 \mu \mathrm{Ci}\left({ }^{35} \mathrm{~S}\right] \mathrm{UTP}$, $150 \mu \mathrm{M}$ each of ATP, CTP and GTP, $12.5 \mathrm{mM}$ dithiothreitol, $20 \mathrm{U}$ RNase inhibitor, and $6 \mathrm{U}$ polymerase. The reaction was incubated for $60-90 \mathrm{~min}$ at $37^{\circ} \mathrm{C}$, treated with DNAase 1 for $15 \mathrm{~min}$ at room temperature, and then probe was separated from unincorporated nucleotides over a Sephadex G50-50 column. The probe was diluted in hybridization buffer to yield $\approx 1.5 \times 10^{6}$ d.p.m. $/ 35 \mu$ l of buffer. Hybridization buffer was $50 \%$ formamide, $10 \%$ dextran sulphate, $3 \times$ standard SSC, $50 \mathrm{mM}$ sodium phosphate buffer $(\mathrm{pH} 7.4), 1 \times$ Denharts solution, and $0.1 \mathrm{mg} / \mathrm{ml}$ yeast. Diluted probe $(35 \mu \mathrm{l})$ was applied to each slide and sections were coverslipped. Slides were placed in sealed plastic boxes lined with filter paper moistened with $50 \%$ formamide. These boxes were wrapped with plastic wrap and incubated at $55^{\circ} \mathrm{C}$ for $16 \mathrm{~h}$. Coverslips were removed, and slides were washed in $2 \times \mathrm{SSC}$. Slides were then incubated in RNase A $(200 \mu \mathrm{g} / \mathrm{ml})$ at $37^{\circ} \mathrm{C}$ for $60 \mathrm{~min}$, washed successively in decreasing concentrations of SSC $(2 \times, 1 \times, 0.5 \times, 0.1 \times)$ and then washed in $0.1 \times \mathrm{SSC}$ at $65^{\circ} \mathrm{C}$ for $60 \mathrm{~min}$. Slides were subsequently washed in distilled water and dehydrated through graded alcohol. Slides were then exposed to BioMax film (Eastman Kodak, Rochester, NY, USA) for $6 \mathrm{~h}$ (ENK), 1 day $(\mathrm{CRH})$ or 11 days $(\mathrm{NT})$. Slides were then dipped in NTB2 emulsion (diluted 1:1; Eastman Kodak, Rochester, NY, USA) and stored at $4{ }^{\circ} \mathrm{C}$ for 1 day (ENK) or 4 weeks (CRH and NT). Emulsion dipped slides, used for photographic purposes, were developed in D-19 developer (Eastman Kodak, Rochester, NY, USA), counterstained with cresyl violet, dehydrated in graded series of alcohol, placed in xylene, and coverslipped with Permount (Fisher Scientific, Pittsburgh, PA, USA). To allow reliable comparisons between groups, sections from each group were processed together.

\section{Double in-situ hybridization}

To determine the number of CRH neurones containing AVP mRNA, we used a double in-situ hybridization protocol of Curran et al. (62), incorporating some modifications from Watts et al. (52). CRH mRNA containing neurones were detected using a digoxigenin (dig) labelled probe, transcribed using a $20 \mu \mathrm{l}$ transcription reaction containing $4 \mu \mathrm{l}$ transcription buffer, $9 \mu \mathrm{l}$ sterile water, $2 \mu \mathrm{l} \mathrm{NTP} \mathrm{solution} \mathrm{(containing} 2 \mu \mathrm{l}$ each of $10 \mathrm{mM}$ ATP, GTP, and CTP, and $1.6 \mu \mathrm{l}$ of $250 \mathrm{nmol}$ dig-UTP (Boehringer Mannheim, Germany), and $0.4 \mu \mathrm{l}$ of $10 \mathrm{mM}$ UTP), $2 \mu \mathrm{l} 0.1 \mathrm{M}$ dithiothreitol, $1 \mu \mathrm{l}$ linearized $\operatorname{DNA}(1 \mu \mathrm{g} / \mu \mathrm{l}), 1 \mu \mathrm{l}$ RNase inhibitor, and $1 \mu \mathrm{l}$ polymerase. AVP mRNA was detected using a $\left.{ }^{35} \mathrm{~S}\right)$-labelled $235 \mathrm{nt}$ probe, generated as described above. Tissue sections were processed as previously described, except that the proteinase $\mathrm{K}$ step was omitted. Thirty-five $\mu \mathrm{l}$ of hybridization buffer containing both the CRH and AVP probes was applied to each slide and sections were coverslipped. Sections were hybridized and washed as described above; after the $0.1 \times \mathrm{SSC}$ wash at $65^{\circ} \mathrm{C}$ the slides were placed in $0.1 \mathrm{M}$ phosphate buffer $(\mathrm{PB}), \mathrm{pH}$ 7.4. The slides were then transferred to a blocking solution $(0.5 \%$ Triton X-100, $0.25 \%$ carageenan, $0.1 \mathrm{M} \mathrm{PB})$ and incubated for $3 \mathrm{~h}$ at $30^{\circ} \mathrm{C}$. The sections were then transferred to fresh blocking solution which contained an alkaline phosphatase (AP)-conjugated antidig (sheep antidig-AP, Fab fragments; Boehringer Mannheim) at a $1: 20,000$ dilution. Sections were incubated for $20 \mathrm{~h}$ at $4{ }^{\circ} \mathrm{C}$. Slides were then washed twice with PB, pH 7.4,

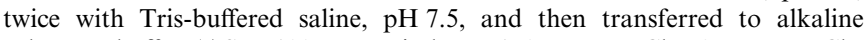
substrate buffer (ASB; $100 \mathrm{mM}$ tris base, $150 \mathrm{mM} \mathrm{NaCl}, 50 \mathrm{mM} \mathrm{MgCl}_{2}$, $\mathrm{pH}$ 9.5). The colour reaction was completed by placing the sections in ASB solution containing 5\% polyvinyl alcohol (w:vol; Sigma, St Louis, MO, USA), $0.26 \%$ NBT(4-nitro blue tetrazolium chloride, Boehringer Mannheim), $0.26 \%$ BCIP (X-phosphate/5-bromo-4-chloro-3-indoyl-phosphate, Boehringer Mannheim) and $0.024 \%$ levamisole (w:vol, Sigma). Slides were incubated in this solution, in the dark, for $72 \mathrm{~h}$ at $4{ }^{\circ} \mathrm{C}$, and then for $24 \mathrm{~h}$ at room temperature. Slides were checked periodically throughout the incubation period to monitor the progress of the colour reaction. After completion of the colour reaction, slides were washed extensively with water, the $\mathrm{Ab}$ was stripped by placing the slides in $0.1 \mathrm{M}$ glycine solution, $\mathrm{pH} 2.2$ for $10 \mathrm{~min}$, and then sections placed in a $2.5 \%$ gluteraldehyde solution for $60 \mathrm{~min}$ at room temperature. Slides were then washed extensively in water, and quickly dehydrated through a series of alcohols. To visualize the $\left({ }^{35} \mathrm{~S}\right)$ signal, slides were dipped in Ilford KD-5 emulsion (Polysciences, Warrington, PA, USA) and exposed for 25 days at $4{ }^{\circ} \mathrm{C}$. Slides were then developed and coverslipped using Aqua-Poly/Mount (Polysciences, Inc., Warrington, PA, USA)

\section{Radioimmunoassay}

Plasma corticosterone concentrations were determined using a previously described assay (63). Briefly, plasma was extracted by heating a $1: 100$ plasma: buffer dilution at $70^{\circ} \mathrm{C}$ for $30 \mathrm{~min}$. Antibody (no. 195 from our laboratory) and ${ }^{3} \mathrm{H}$ corticosterone (Amersham; Arlington Heights, IL, USA) were added and allowed to incubate overnight. After incubation, bound trace was separated from unbound trace using charcoal dextran. All samples were run in two assays, with the samples from different experimental groups equally distributed between the two assays. Assay sensitivity was $1 \mathrm{pg} / \mathrm{ml}$. Intra-and interassay variability were $3.6 \%$ and $9.0 \%$, respectively.

\section{Data analysis}

For all analysis, the experimenter was blind to the experimental group of the sections being analysed. For the single labelling studies, changes in mRNA levels were determined using the public domain NIH Image software (written by Wayne Rasband at the NIH; version 1.6) on a Power Macintosh 8100/80 AV computer. Relative optical density was determined for the area of interest from the X-ray film; positive signal was considered to be optical density levels above a threshold level which was 3 SD above the mean optical density of the background signal. Values reflect integrated optical density, which incorporates both the intensity and area of positive signal. CRH, ENK, and NT mRNA levels were each determined from three sections localized in the middle regions of the PVN, where the highest levels of CRH mRNA are detected (64).

CRH mRNA levels within the central nucleus of the amygdala (CeA) were also determined. Integrated optical density measurements were determined from three sections showing the highest CRH mRNA levels within this region.

For the double labelling studies, emulsion-dipped sections were examined using a Leica DMR microscope. Initially, the number of neurones containing dig-labelled CRH mRNA was determined. These neurones were determined to contain AVP mRNA if there was a distinct clustering of silver grains, above background levels, that was centred over a positive CRH neurone. 


\section{Statistical analysis}

Significant differences in mRNA integrated optical density measurements, the number of dig-labelled CRH neurones, and the number of CRH/AVP double labelled neurones among the groups were determined using a one-way anova, followed by Fisher PLSD post-hoc tests. Significant differences among plasma corticosterone values were determined using a repeated-measures anova, followed by Scheffe post-hoc tests. Significance was $\mathrm{P} \leqslant 0.05$. Additionally, for all mRNA analysis, the chamber control groups group values were not significantly different from home cage control, so for reasons of clarity only data from home cage controls is illustrated.

\section{Acknowledgements}

The authors would like to thank Sharon Burke and Lee Silbert for their excellent technical assistance. We would also like to thank Drs R. C. Thompson and P. Dobner for their generous gifts of cDNA. Drs Heidi Day, Sara Kollack-Walker, and David Parfitt provided valuable advice and insightful comments during the preparation of this manuscript. This work was supported by MH10715 (DLH), MH42251 (HA and SJW), and MH50479 (SFM).

\section{Accepted 3 August 1998}

\section{References}

1 Herman J, Prewitt M-F, Cullinan W. Neuronal circuit regulation of the hypothalamo-pituitary-adrenocortical stress axis. Crit Rev Neurobiol 1996; 10: 371-394.

2 Li H-Y, Ericsson A, Sawchenko P. Distinct mechanisms underlie activation of hypothalamic neurosecretory neurons and their medullary catecholaminergic afferents in categorically different stress paradigms. Proc Natl Acad Sci 1996; 93: 2359-2364.

3 Vale W, Vaughn J, Smith M, Yammamoto G, Rivier J, Rivier C. Effects of synthetic ovine corticotropin-releasing factor, glucocorticoids, catecholamines, neurohypophysial peptides, and other substance on cultured corticotropic cells. Endocrinol 1983; 113: 1121-1131.

4 Antoni F. Hypothalamic control of adrenocorticotropin secretion: advances since the discovery of 41-residue cortiocotropin-releasing factor. Endocrine Rev 1986; 7: 351-378.

5 Ceccatelli S, Eriksson M, Hökfelt T. Distribution and coexistence of corticotropin-releasing factor-, neurotensin-, enkephalin-, cholecystokinin-, galanin-, and vasoactive intestinal polypeptide/peptide histidine isoleucine-like peptides in the parvocellular part of the paraventricular nucleus. Neuroendocr 1989; 49: 309-323.

6 Merchenthaler I. Enkephalin-immunoreactive neurons in the parvicellular suddivisions of the paraventricular nucleus project to the external zone of the median eminence. J Comp Neurol 1992; 326: 112-120.

7 Pretel S, Piekut D. Coexistence of corticotropin-releasing factor and enkephalin in the paraventricular nucleus of the rat. J Comp Neurol 1990; 294: 192-201.

8 Plotsky P, Bruhn T, Vale W. Evidence for multifactoral regulation of the adrenocorticotropin secretory response to hemodynamic stimuli. Endocrinol 1985; 116: 633-639.

9 Plotsky P, Bruhn T, Vale W. Hypophysiotropic regulation of adrenocorticotropin secretion in response to insulin-induced hypoglycemia. Endocrinol 1985; 117: 323-329.

10 Watts A. Ether anesthesia diffentially affects the content of preprocorticotropin-releasing hormone, prepro-neurotensin/neuromedin $\mathrm{N}$ and prepro-enkephalin mRNAs in the hypothalamic paraventricular nucleus of the rat. Brain Res 1991; 544: 353-357.

11 Ceccatelli S, Orazzo C. Effect of different types of stressors on peptide messenger ribonucleic acids in the hypothalamic paraventricular nucleus. Acta Endocrinol 1993; 128: 485-492.

12 Harbuz M, Lightman S. Responses of hypothalamic and pituitary mRNA to physical and psychological stress in the rat. J Endocrinol 1989; 122: $705-711$.

13 Maier S, Drugan R, Grau J. Controllability, coping behavior, and stressinduced analgesia in the rat. Pain 1982; 12: 47-56.

14 Telner J, Merali Z, Singhal R. Stress controllability and plasma prolactin levels in the rat. Psychoneuroendo 1982; 7: 361-364.

15 Murison R, Isaksen E. Gastric ulceration and adrenocortical activity after inescapable and escapable pre-shock in rats. Scan J Psychol. 1982; 1(Suppl): 133-137.

16 Weiss J, Goodman P, Losito B, Corrigan S, Charry J, Bailey W. Behavioral depression produced by an uncontrollable stressor: relationship to norepeinephrine, dopamine, and serotonin levels in various regions of rat brain. Brain Res Rev 1981; 3: 167-205.

17 Shors T, Seib T, Levine S, Thompson R. Inescapable versus escapable shock modulates long-term potentiation in the rat hippocampus. Science 1989; 244: 224-226.

18 Seligman M, Weiss J. Coping Behavior: Learned helplessness, physiological change, and learned activity. Behav Res Ther 1980; 18: 459-512.

19 Maier S, Ryan S, Barksdale C, Kalin N. Stressor controllability and the pituitary-adrenal system. Behav Neuroscience 1986; 100: 669-674.

20 Prince C, Anisman H. Situation specific effects of stressor controllability on plasma corticosterone changes in mice. Pharmacol Biochem Behav 1990; 37: 613-621.

21 Swenson R, Vogel W. Plasma catecholamine and corticosterone as well as brain catechoamine changed during coping in rats exposed to stressful footshock. Pharm Biochem Behav 1983; 18: 689-693.

22 Haracz J, Minor T, Wilkins J, Zimmerman E. Learned helplessness: an experimental model of the DST in rats. Biol Psychiatry 1988; 23: 388-396.

23 Compas B, Orosan P, Grant K. Adolescent stress and coping: Implications for psychopathology during adolescence. $J$ Adolescence 1993; 16: 331-349.

24 Paykel E. Life events, socisl support, and depression. Acta Psychiatr Scand. 1994; 377 (Suppl): 50-58.

25 Young E, Haskett R, Grunhaus L, Pande A, Weinberg V, Watson S, Akil H. Increased activation of the hypothalamic-pituitary-adrenal axis in depressed patients. Arch Gen Psychiatry 1994; 51: 701-707.

26 Matthews J, Akil H, Greden J, Charney D, Weinberg V, Rodenbaum A, Watson S. $\beta$-Endorphin $/ \beta$-Lipotropin immunoreactivity in endogenous depression. Arch Gen Psychiatry 1986; 43: 374-381.

27 Purba J, Hoogendijk W, Hofman M, Swaab D. Increased number of vasopressin- and oxytocin-expressing neurons in the paraventricular nucleus of the hypothalamus in depression. Arch Gen Psychiatry 1996; 53: $137-143$.

28 Raadsheer F, Hoogendijk W, Stan F, Tilders F, Swaab D. Increased numbers of corticotropin-releasing hormone expressing neurons in the hypothalamic paraventricular nucleus of depressed patients. Neuroendocrinology 1994; 60: 436-444.

29 Modell S, Yassouridis A, Huber J, Holsboer F. Corticosteroid receptor function is decreased in depressed patients. Neuroendo 1997; 65: 216-222.

30 Romero M, Plotsky P, Sapolsky R. Patterns of adrenocorticotropin secretagogue release with hypoglycemia, novelty, and restraint after colchicine blockade of axonal transport. Endocrinol 1993; 132:. 199.

31 Romero L, Levine S, Sapolsky R. Patterns of adrenocorticotropin secretagog release in response to social interactions and various degrees of novelty. Psychoneuroendo 1995; 20: 183-191.

32 Darlington D, Baraclough C, Gann D. Hypotensive hemorrhage elevates corticotropin-releasing hormone messenger ribonucleic acid (mRNA) but not vasopressin mRNA in the rat hypothalamus. Endocrinol 1992; 130: 1281-1288.

33 Miller A, Spencer R, Pulera M, Kang S, McEwen B, Stein M. Adrenal steroid receptor activation in rat brain and pituitary following dexamethasone: Implications for the dexamethaone suppression test. Biol Psychiatry 1992; 32: 850-869.

34 Maier S. Learned helplessness and animal models of depression. Prog Neuro-Psycholopharmacol Biol Psychiat 1984; 8: 435-446.

35 Schmidt E, Binnekade R, Janszen A, Tilders F. Short stressor induced long-lasting increases of vasopressin stores in hypothalamic corticotropinreleasing hormone $(\mathrm{CRH})$ neurons in adult rats. J Neuroendocrinol 1996; 8: $703-712$.

36 Ma X-M, Levy A, Lightman S. Emergence of an isolated arginine vasopressin (AVP) response to stress after repeated restraint: a study of both AVP and corticotropin-releasing hormone messenger ribonucleic acid (RNA) and heteronucleur RNA. Endocrinol 1997; 138: 4351-4357.

37 Wotjak C, Kubota M, Liebsch G, Montkowski A, Holsboer F, Neumann I, Landgraf R. Release of vasopressin within the rat paraventricular nucleus in response to emotional stress: a novel mechanism of regulating adrenocorticotropic hormone secretion? J Neurosci 1996; 16: 7725-7732.

38 Imaki T, Naruse M, Harada S, Chikada N, Imaki J, Onodera H, Demura H, Vale W. Corticotropin-releasing factor up-regulates its own 


\section{Stressor controllability and PVN mRNA levels}

receptor mRNA in the paraventricular nucleus of the hypothalamus. Mol Brain Res 1996; 38: 166-170.

39 Nicot A, Rowe W, de Kloet E, Betancur C, Jessop D, Lightman S, Quirion R, Rostene W, Berod A. Endogenous neurotensin regulates hypothalamic-pituitary-adrenal axis activity and peptidergic neurons in the rat hypothalamic paraventricular nucleus. J Neuroendo 1997; 9: 263-269.

40 Rowe W, Viau V, Meaney M, Quirion R. Stimulation of CRH-mediated ACTH secretion by central administration of neurotensin: evidence for the participation of the paraventricular nucleus. J Neuroendo 1995; 7: 109-117.

41 Rowe W, Nicot A, Sharma S, Gully D, Walker C, Rostene W, Meaney M, Quirion R. Central administration of the neurotensin receptor antagonist, SR48692, modulates diurnal and stress-related hypothalamicpituitary-adrenal acitivity. Neuroendocrinology 1997; 66: 75-85.

42 Nicholson S, Adrian T, Gillham B, Jones M, Bloom S. Effect of hypothalamic neuropeptides on corticotrophin release form quarters of rat anterior pituitary gland in vitro. $J$ Endocr 1984; 100: 219-226.

43 Brooks N, Challis J. Effects of CRF, AVP, and opioid peptides on pituitary-adrenal responses in sheep. Peptides 1989; 10: 1291-1293.

44 Giusti M, Marini G, Uggias B, Sessarego P, Besser G, Grossman A, Giordano $\mathrm{G}$. The effect of a met-enkephalin analogue on growth hormone, prolactin, gonadotropins, cortisol, and thyroid stimulating hormone in healthy elderly men. Acta Endocrinologica 1992; 127: 205-209.

45 Iyengar S, Kim H, Wood P. Kappa opiate agonists modulate the hypothalamic-pituitary-adrenocortical axis in the rat. J Pharm Exp Therapeutics 1986; 238: 429-436.

46 Allolio B, Deuss U, Kaulen D, Leonhardt U, Kallabis D, Hamel E, Winkelmann W. FK 33-824, a Met-Enkaphalin analog, blocks corticotropin-releasing hormone-induced adrenocorticotropin secretion in normal subjects but not in patients with Cushing's disease. Endocrinology 1986; 63: 1427-1431.

47 Buckingham J, Cooper T. Differences in hypothalamo-pituitaryadrenocortical activity in the rat after acute and prolonged treatment with morphine. Neuroendocrinology 1984; 38: 411-417.

48 Sawchenko P. Adrenalectomy-induced enhancement of CRF and vasopressin immunoreactivity in parvocellular neurosecretory neurons: anatomic, peptide, and steroid specificity. J Neurosci 1987; 7: 1093-1106.

49 Swanson L, Simmons D. Differential steroid hormone and neural influences on peptide mRNA levels in CRH cells of the paraventricular nucleus: a hybridization histochemical study in the rat. J Comp Neurol 1989; 285: 413-435.

50 Watts A, Sanchez-Watts G. Region-specific regulation of neuropeptide mRNAs in rat limbic forebrain neurones by aldosterone and corticosterone. J Physiol 1995; 3: 721-736.

51 Swanson L. Biochemical switching in hypothalamic circuits mediating responses to stress. Prog Brain Res 1991; 87: 181-200.
52 Watts A, Sanchez-Watts G. Physiological regulation of peptide messenger RNA colocalization in rat hypothalamic paraventricular medial parvicellular neurons. J Comp Neurol 1995; 352: 501-514.

53 Watkins L, Wiertelak E, Maier S. The amygdala is necessary for the expresssion of conditioned but not unconditioned analgesia. Behav Neuroscience 1993; 107: 402-405.

54 Koob G, Heinrichs S, Pich E, Menzaghi F, Baldwin H, Miczek K, Britton K. The role of corticotropin-releasing factor in behavioral responses to stress. In: Chadwick DJ, Marsh J, Ackrill K, eds. Corticotropin-releasing Factor (Ciba Foundation Symposium 172). Chichester: Wiley, 1993: 277-295.

55 Maier S, Grahn R, Kalman B, Sutton L, Wiertelak E, Watkins L. The role of the amygdala and dorsal raphe nucleus in mediating the behavioral consequences of inescapable shock. Behav Neuroscience 1993; 107: 377-388.

56 Mamalaki E, Kvetnansky R, Brady LS, Gold PW, Herkenham M. Repeated immobilization stress alters tyrosine hydroxylase, corticotropinreleasing hormone and corticosteroid receptor messenger ribonucleic acid levels in rat brain. J Neuroendocrinol 1992; 4: 689-699.

57 Makino S, Gold P, Schulkin J. Effects of corticosterone on CRH mRNA and content in the bed nucleus of the stria terminalis: comparison with the effects on the central nucleus of the amygdala and the paraventricular nucleus of the hypothalamus. Brain Res 1994; 657: 141-149.

58 Day H, Akil H. Systemic and central administration of interleukin-1-beta induces differential patterns of c-fos activation in rat brain: implications for mechanism of action. In: Society for Neuroscience Annual Meeting, San Diego, 1995. Washington: The Society for Neuroscience.

59 Grahn R, Kalman B, Brennan F, Watkins L, Maier S. The elevated plus-maze is not sensitive to the effect of stressor controllability in rats. Pharm Biochem Behav 1995; 52: 565-570.

60 Schafer K-H, Herman J, Watson S. In situ hybridization histochemistry. In: London E, ed. Imaging Drug Action in the Brain. Boca Raton: CRC Press, 1993: 337-377.

61 Alexander M, Miller M, Dorsa D, Bullock B, Melloni R, Dobner P, Leeman S. Distribution of neurotensin/neuromedi $N$ mRNA in rat forebrain: Unexpected abundance in hippocampus and subiculum. Proc Natl Acad Sci 1989; 86: 5202-5206.

62 Curran E, Watson S. Dopamine receptor mRNA expression patterns by opioid peptide cells in the nucleus accumbens of the rat: A double in situ hybiridization study. J Comp Neurol 1995; 361: 57-76.

63 Day HEW, Akil H. Differential pattern of $c$-fos mRNA in rat brain following central and systemic adminstration of interleukin-1-Beta: implications for mechanism of action. Neuroendocrinol 1996; 63: 207-218.

64 Herman J, Cullinan W, Watson S. Involvement of the bed nucleus of the stria terminalis in tonic regulation of paraventricular hypothalamic CRH and AVP mRNA expression. J Neuroendocrinol 1994; 6: 433-442. 